\title{
COMPARISON OF REBOUND NUMBERS FOR M20 CONCRETE WITH SILICA FUME
}

\author{
S.S.Kumar ${ }^{1}$, T.Anitha ${ }^{2}$ \\ ${ }^{\text {I}}$ P.G Student, M.E., Structural Engineering, Gnanamani college of Engineering, Namakkal \\ ${ }^{2}$ Assistant professor, Gnanamani college of Engineering, Namakkal
}

\begin{abstract}
The concrete is one of the most important for all the construction work. The main role of the concrete based on cement, steel. To improve the strength and durable of the concrete to add the admixture. Silica fume is added to the fresh concrete to improve the durability, ductility and strengthen of the concrete. Because, the silicon dioxide with carbon it which gives silica and carbon monoxide. It is very good permeability and also abrasion resistance. For this present study M20 grade of concrete shall be designed, partial replacement of cement with silica fume will be incorporating the strength for varying percentage, such as $0 \%$, $5 \%, 10 \%, 15 \%, 20 \%$ by weight of cement with rebound hammer value Vs compressive strength.
\end{abstract}

Keywords: Ordinary Portland cement, Micro silica, compressive strength, tensile strength, Flexural strength ****

\section{INTRODUCTION}

Micro silica produced by the raw materials such as Carbon (coke, coal, wood chips), Quartz with temperature at 2000 degree Celsius will get Silicon metal, off gas into the Bag house filter finally get the powder form. It's color varying from white and gray .It is very fine particles to fill the voids in the concrete and its to improve the strength.

Micro silica is also available in the packaging. It contain silicon dioxide is more than $95 \%$,moisture content $1 \%$,bulk density range from $450-650 \mathrm{~kg} / \mathrm{m} 3$. The $\mathrm{PH}$ value is 6 to 6.5.The carbon content is higher than others. It is very good binder between the aggregates and also reduced with shrinkage. (1)

Micro silica is good thermal conductivity and reducing the bleeding of the concrete

\section{BACKGROUND/RESEARCH SIGNIFICANCE}

\subsection{Materials}

1. CEMENT: - The OPC 43 grade cement is used.

Table1: Physical properties of cement:

\begin{tabular}{|l|l|l|}
\hline S.No & Characteristics & $\begin{array}{l}\text { Value obtained } \\
\text { experimentally }\end{array}$ \\
\hline 1 & Normal consistency & $29 \%$ \\
\hline 2 & $\begin{array}{l}\text { Fineness (90 micron } \\
\text { sieve) }\end{array}$ & $1 \%$ \\
\hline 3 & Initial Setting time & 32 minutes \\
\hline 4 & Specific gravity & 2.97 \\
\hline
\end{tabular}

Compressive Strength of Cement:-

\begin{tabular}{|l|l|}
\hline Days & $\begin{array}{l}\text { Compressive Strength in } \\
\mathrm{MPa}\end{array}$ \\
\hline 7 Days & 23 \\
\hline 14 Days & 33 \\
\hline 28 DAYS & 43 \\
\hline
\end{tabular}

2. FINE AGGREGATE:- The local river sand is used.

Table 2: Physical Properties of Fine Aggregate:

\begin{tabular}{|l|l|l|}
\hline S. No & Characteristics & $\begin{array}{l}\text { Value obtained } \\
\text { experimentally }\end{array}$ \\
\hline 1 & Fineness & 2.60 \\
\hline 2 & Specific gravity & 2.60 \\
\hline
\end{tabular}

3. COARSE AGgREGATE: Locally available coarse aggregate used.

Table 3: Physical properties of coarse aggregate

\begin{tabular}{|l|l|l|}
\hline $\begin{array}{l}\text { S. } \\
\text { No }\end{array}$ & Characteristics & $\begin{array}{l}\text { Value obtained } \\
\text { experimentally }\end{array}$ \\
\hline 1 & Fineness & 6.29 \\
\hline 2 & Specific gravity & 2.60 \\
\hline
\end{tabular}

4. SILICA-FUME:- Silica-fume is obtained from Nuchems Ltd, Bangalore in Karnataka state.(2)

Table 4: Physical properties

\begin{tabular}{|c|c|}
\hline $\begin{array}{l}\text { MICRO SILICA } \\
\text { Properties }\end{array}$ & Fumes) \\
\hline Product & $\begin{array}{l}\text { Crystalline } \\
\text { (quartz) }\end{array}$ \\
\hline
\end{tabular}




\begin{tabular}{|l|l|l|}
\hline & Molecular Formula & $\mathrm{SiO} 2$ \\
\hline & Physical State & Powder \\
\hline $\begin{array}{l}\text { Appearance and Odor } \\
\text { Specific Gravity }(\mathrm{H} 20\end{array}$ & $\begin{array}{l}\text { White Powder, } \\
\text { Odorless }\end{array}$ \\
\hline Boiling Point & $2.65 \mathrm{~g} / \mathrm{cm}$ \\
\hline & Melting & $2230^{\circ} \mathrm{F}$ \\
\hline & Solubility in Water & $1710^{\circ} \mathrm{F}$ \\
\hline & Molecular Weight & Insoluble \\
\hline & Solvent Solubility & $\begin{array}{l}\text { Soluble } / \mathrm{mol} \\
\text { hydrofluoric acid. } \\
\text { Slightly soluble in } \\
\text { alkali and hot } \\
\text { concentrated } \\
\text { phosphoric acid. } \\
\text { Insoluble in acids } \\
\text { and organic } \\
\text { solvents }\end{array}$ \\
\hline
\end{tabular}

5. WATER: - It is used for casting and curing of specimen.

\section{EXPERIMENTAL STUDY}

In general the mix design (M20) is arrived based on the physical properties of materials and according to with IS: 10262:2009

Table 5: Mix-proportion

\begin{tabular}{|l|l|l|l|}
\hline $\begin{array}{l}\text { Water } \\
\text { cement } \\
\text { ratio }\end{array}$ & Cement & $\begin{array}{l}\text { Fine } \\
\text { Aggregate }\end{array}$ & $\begin{array}{l}\text { Coarse } \\
\text { Aggregate }\end{array}$ \\
\hline 0.50 & 1 & 1.52 & 3.15 \\
\hline
\end{tabular}

\subsection{Compressive Strength Test}

Totally 45 concrete cubes were cast and it is allowed for 7 days, 14 days and 28 days curing. After during, cubes were tested in compression Testing Machine (CTM) to determine the ultimate load. Replacement made of $0 \%, 5 \%, 10 \%, 15 \%$, and $20 \%$. For this study the water cement ratio of 0.50 is maintained uniformly.

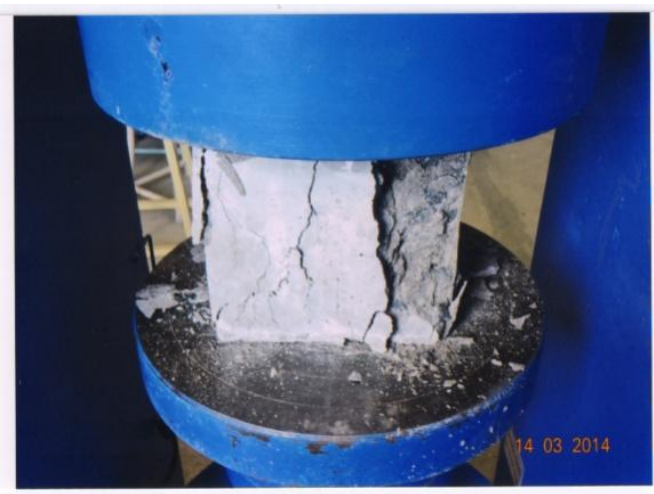

Fig 1
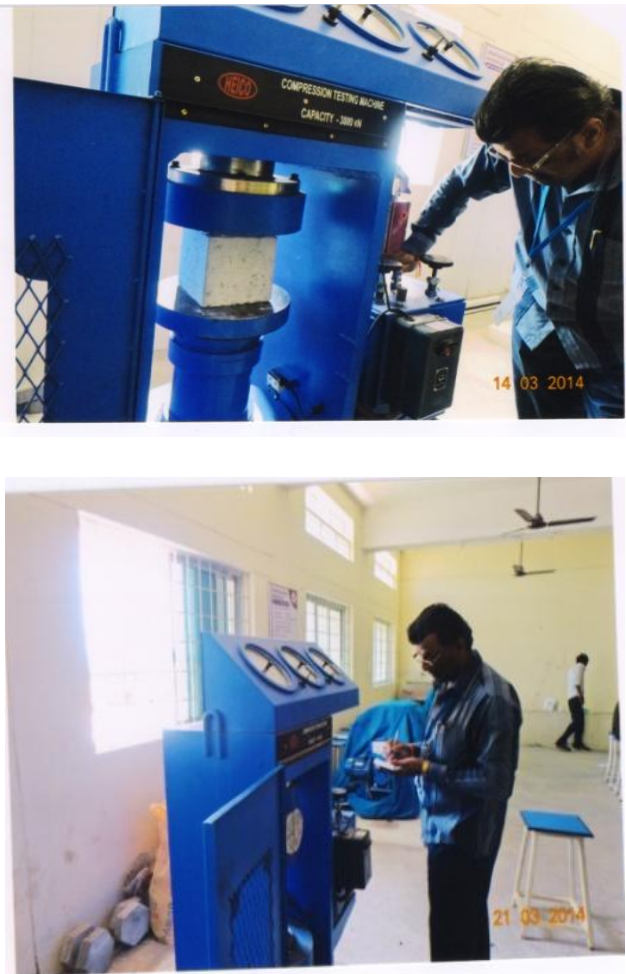

Fig2: Compressive strength of Cubes

Table 6: Compressive Strength of Cubes

\begin{tabular}{|l|l|l|l|}
\hline $\begin{array}{l}\% \\
\text { Silica } \\
\text { fume } \\
\text { used }\end{array}$ & $\begin{array}{l}7 \text { days } \\
\text { Compressive } \\
\text { Strength in } \\
\mathrm{MPa}\end{array}$ & $\begin{array}{l}\text { 14 days } \\
\text { Compressive } \\
\text { Strength in } \\
\mathrm{MPa}\end{array}$ & $\begin{array}{l}28 \\
\text { Compressive } \\
\text { Strength in } \\
\mathrm{MPa}\end{array}$ \\
\hline $0 \%$ & 17.77 & 20.31 & 25.39 \\
\hline $5 \%$ & 19.55 & 22.34 & 27.93 \\
\hline $10 \%$ & 21.33 & 24.38 & 30.47 \\
\hline $15 \%$ & 23.11 & 26.41 & 33.01 \\
\hline $20 \%$ & 24.44 & 27.93 & 34.92 \\
\hline
\end{tabular}

\subsection{Tensile Strength Test}

Totally 30 cylinders of M20 grade concrete were cast. Replacement made of $0 \%, 5 \%, 10 \%, 15 \%$ and $20 \%$. For the study the water cement ratio of 0.50 is maintained uniformly.

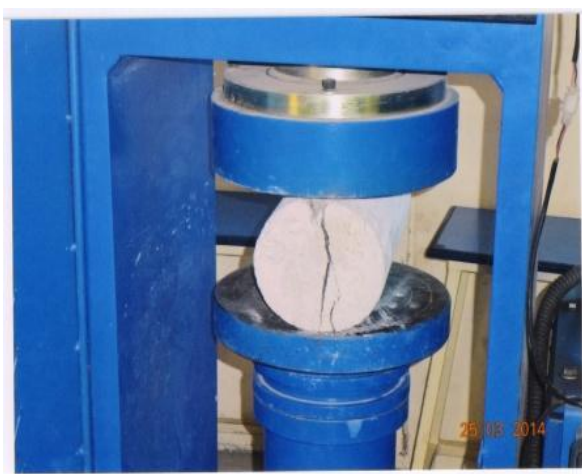

Fig3. Tensile Strength Cylinders 
Table 7: Tensile Strength of Cylinders

\begin{tabular}{|l|l|l|l|}
\hline $\begin{array}{l}\text { \% of } \\
\text { Silica } \\
\text { fume } \\
\text { used }\end{array}$ & $\begin{array}{l}\text { 7 days } \\
\text { Tensile } \\
\text { Strength in } \\
\mathrm{MPa}\end{array}$ & $\begin{array}{l}\text { 14 days } \\
\text { Tensile } \\
\text { Strength } \\
\text { in } \mathrm{MPa}\end{array}$ & $\begin{array}{l}28 \text { days } \\
\text { Tensile } \\
\text { Strength } \\
\text { in MPa }\end{array}$ \\
\hline $0 \%$ & 1.36 & 1.56 & 1.94 \\
\hline $5 \%$ & 1.36 & 1.56 & 1.94 \\
\hline $10 \%$ & 1.36 & 1.56 & 1.94 \\
\hline $15 \%$ & 1.42 & 1.63 & 2.03 \\
\hline $20 \%$ & 1.48 & 1.69 & 2.12 \\
\hline
\end{tabular}

\subsection{Flexural Strength Test}

Totally 36 prisms of M20 grade concrete were cast. Replacement made of $0 \%, 5 \%, 10 \%, 15 \%$ and $20 \%$. For the study the water cement ratio of 0.50 is maintained uniformly.

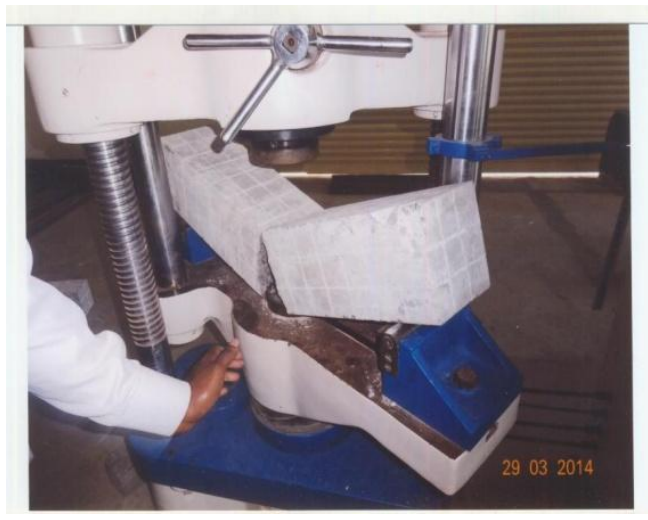

Fig 4: Flexural Strength test

Table 8: Flexural Strength of Prisms:

\begin{tabular}{|l|l|l|}
\hline $\begin{array}{l}\% \text { of } \\
\text { Silica } \\
\text { fume } \\
\text { used }\end{array}$ & $\begin{array}{l}\text { 14 days } \\
\text { Tensile } \\
\text { Strength in } \\
\mathrm{MPa}\end{array}$ & $\begin{array}{l}28 \text { days } \\
\text { Tensile } \\
\text { Strength in } \\
\mathrm{MPa}\end{array}$ \\
\hline $0 \%$ & 2.09 & 2.99 \\
\hline $5 \%$ & 2.23 & 3.19 \\
\hline $10 \%$ & 2.36 & 3.37 \\
\hline $15 \%$ & 2.47 & 3.54 \\
\hline $20 \%$ & 2.61 & 3.74 \\
\hline
\end{tabular}

\section{RESULT AND DISCUSSION}

The results obtained from the experimental investigations are shown graphically. All the values are the average of the three specimens tested. The compression strength of cubes, split tensile strength of cylinders, flexural strength of prisms is shown in figure 5, 6, and 7 respectively.

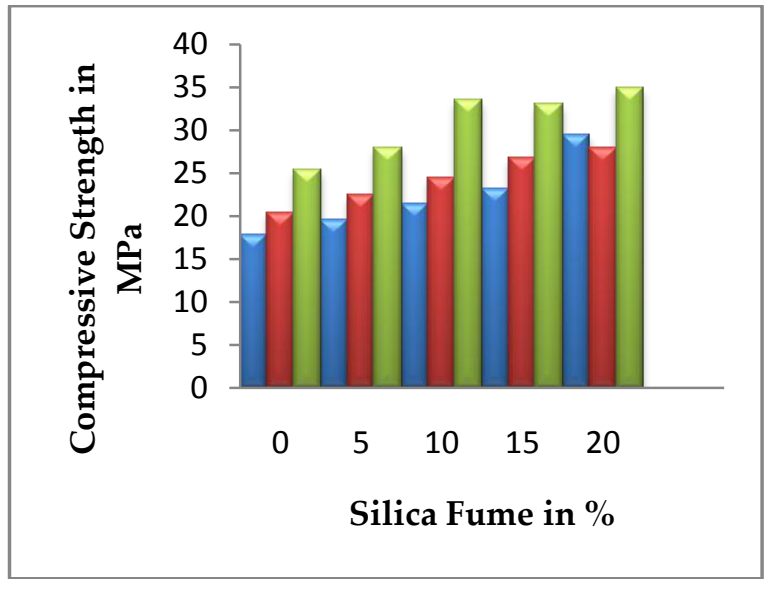

Fig 5: Compressive strength at 7, 14, and 28 days with $0 \%$, $5 \%, 10 \%, 15 \%$, and $20 \%$ of silica fume.

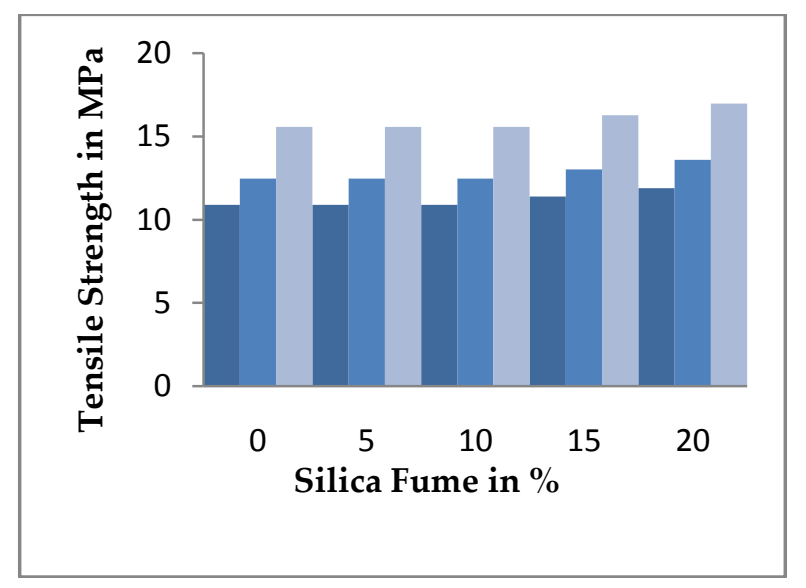

Fig 6: Tensile Strength at 7, 14, and 28 days with $0 \%, 5 \%$, $10 \%, 15 \%$, and $20 \%$ of silica fume.

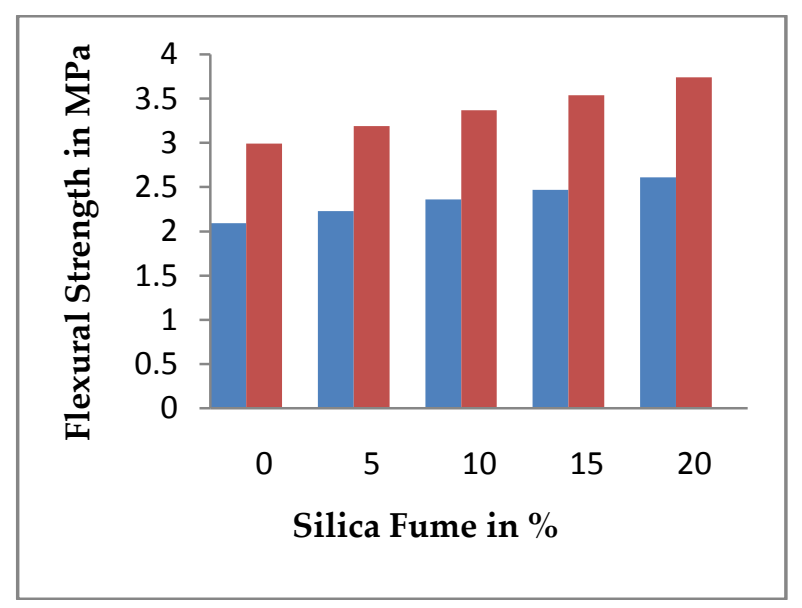

Fig 7: Flexural Strength at 14, and 28 days with $0 \%, 5 \%$, $10 \%, 15 \%$, and $20 \%$ of silica fume. 


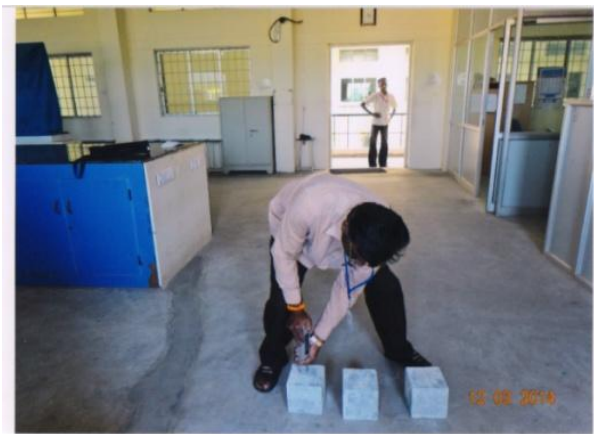

Fig 8: Rebound hammer compressive strength test

Table 9: Comparison of Compressive testing machine $\mathrm{V}_{\mathrm{S}}$ Rebound Number

\begin{tabular}{|l|l|l|}
\hline $\begin{array}{l}\text { Silica } \\
\text { fume } \\
\text { used }\end{array}$ & $\begin{array}{l}\text { Days in } \\
\text { Compressive } \\
\text { Strength in } \\
\text { machine MPa }\end{array}$ & $\begin{array}{l}\text { 28Days } \\
\text { Compressive } \\
\text { Strength in Rebound } \\
\text { Number in MPa }\end{array}$ \\
\hline $0 \%$ & 25.39 & 20 \\
\hline $5 \%$ & 27.93 & 24 \\
\hline $10 \%$ & 30.47 & 26 \\
\hline $15 \%$ & 33.01 & 28.50 \\
\hline $20 \%$ & 34.92 & 31 \\
\hline
\end{tabular}

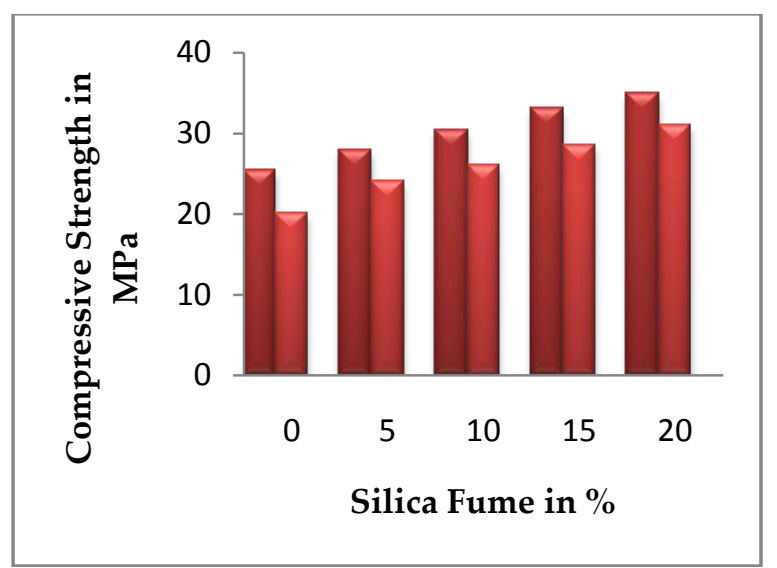

Fig 9: Comparison of Compressive testing machine $V_{S}$ Rebound Number Value

\section{CONCLUSIONS}

- After the 28 days the compressive strength of the cube is little higher than to compare the Rebound number.

- Rebound number clear value obtained by the conventional concrete.

- $\quad$ Rebound number in Silica fume mix proportion is underestimate value of the strength.

\section{ACKNOWLEDGEMENTS}

I would like to thank for supplying Silica fume by Nuchems(P)Ltd, Bangalore in Karnataka State.

\section{REFERENCES}

[1] Pawade Prashant.Y, Nagarnaik P.B, Pande.A.M, (2011) "Influence of Silica fume in enhancement of compressive strength, flexural strength of steel fiber concrete and their relationship", International Journal of Civil and Structural Engineering, Vol.2, No.1, pp.43-55.

[2] Mohammad Panjehpour, Abang Abdullah Abang ALI, Ramazan Demirboga (2011),“ A Review for Characterization of Silica Fume and its effects on concrete properties" ,International Journal of Sustainable Construction Engineering and Technology,Vol.2,Issue 2,pp.1-7.

[3] IS:383-1970,"Indian standards specification for Coarse and Fine aggregates from natural sources for concrete", Bereau of Indian standards, New Delhi.

[4] IS:10262-1999"Recommended guide lines for concrete mix design", Bureau of Indian standards, New Delhi.

[5] IS:516-1959, "Methods of tests for strength of concrete", Bureau of Indian standards, New Delhi.

[6] IS:2386-1963, "Indian standard code of practice for methods of test for Aggregate concrete" Indian standard Institution, New Delhi.

[7] IS:456-2000,"Plain \& Reinforced concrete code of practice", Bureau of Indian standards, New Delhi.

[8] Concrete Technology by M.S .Shetty, published by S.Chanda and company Ltd, New Delhi.

[9] Concrete Technology by M.L.Gambir published by Tata McGraw-Hill Ltd, New Delhi. 